\title{
Nested Markets, Food Networks, and New Pathways for Rural Development in Brazil
}

\author{
Sergio Schneider ${ }^{1, *}$, Natália Salvate ${ }^{2}$ and Abel Cassol ${ }^{3}$ \\ 1 Programas de Pós-Graduação em Desenvolvimento Rural e Sociologia, \\ Universidade Federal do Rio Grande do Sul, Porto Alegre 90040-060, Brazil \\ 2 Programa de Pós-Graduação em Desenvolvimento Rural, Universidade Federal do Rio Grande do Sul, \\ Porto Alegre 90040-060, Brazil; nataliasalvatebrasil@gmail.com \\ 3 Programa de Pós-Graduação em Sociologia, Universidade Federal do Rio Grande do Sul, \\ Porto Alegre 91509-900, Brazil; abelcassol@hotmail.com \\ * Correspondence: schneide@ufrgs.br; Tel.: +55-51-3308-6635
}

Academic Editor: Gbadebo Oladosu

Received: 31 May 2016; Accepted: 12 November 2016; Published: 22 November 2016

\begin{abstract}
This paper applies the frameworks of nested markets and alternative food networks to two empirical cases in the state of Rio Grande do Sul, Brazil, aiming to analyse the construction and dynamics of these markets in order to demonstrate how their dimensions of quality, location, and nature are built and sustained, especially with regard to their interface with broader markets and their contributions to rural development practices, policies, and processes. The paper focuses on the study of rural tourism in Caminhos de Pedra Route, in the municipality of Bento Gonçalves, and the Farmers' Market, in the municipality of Passo Fundo. Both cases represent alternative practices and processes of rural development and bear features that associate them to the nested markets. It is noteworthy that the influence of conventional food markets in these cases shows that nested markets do not operate in isolation but coexist and are continuously in connection with broader agri-food markets. In this sense, despite being subject to criticism and showing limitations, nested markets constitute increasingly robust strategies for rural development practices, processes, and policies, being able to create opportunities for families' livelihood in rural areas.
\end{abstract}

Keywords: nested markets; food network; markets; rural development

\section{Introduction}

The current situation of food production and consumption has been increasingly called into question. On the one hand, the modern agri-food system - which is vertically integrated and controlled by large private corporations-has the merit of increasing food production and productivity (supply) and consequently decreasing prices. On the other hand, such success was accompanied by a number of negative externalities, whether social (inequality and exclusion of small farmers, food insecurity), economic (increase of squeeze on farming), or environmental (climate change and deforestation) [1].

In this context, there has been intense debate and controversy regarding the practices, processes, and logic that underlie the conventional system of food production and consumption, which result in criticism about the ways of doing it. On the production side, there are sound arguments supporting the search for alternative and more sustainable mechanisms and practices, which could contribute to the improvement of small farmers' living conditions, the preservation of biodiversity, and the natural basis on which the food chain is grounded. On the consumption side, criticism highlights food waste and overconsumption, which ultimately affect food safety and the health of populations [2,3]. (As regards the theoretical field, this process can be recognized in the works of various authors who have claimed the limitations of the "productivist" [4] or the "agro-industrial" [5] paradigms of food production 
and consumption. They highlight the strong potential of newly emerging sustainable practices and processes for the formation of a "rural development paradigm" [6] or an "integrated and territorial agri-food paradigm" [5]).

A key issue within these debates refers to the role of agri-food markets. A wide range of interpretations is in place, ranging from the most resigned and tolerant stances on the so-called "market failures" to harsher criticism about the power of concentration and the exclusion that the corporate and globalized food systems have been imposing. In response to these more structuralist perspectives, some contrasting views have emerged that seek to enhance the role of the agents in processes of markets' construction [7]. From this perspective, the markets are seen as strategic spaces in which new services and products can emerge and practices that are distinct from those found in the conventional system can consolidate, thus becoming concrete expressions of new rural development processes [8,9].

Characterized by operation and management logic that are distinct from those of conventional markets, which presume a positive and formal relationship between supply and demand, these newly designed markets have been deemed able to establish new connections between actors and to overcome/resolve some of the limits and problems posed by the conventional system of production and consumption. In particular, this approach suggests that the food supply chains should be understood and analysed as value chains [10] that can mobilize and ascribe meaning and significance to both foods themselves and the ways of producing and consuming food, and also develop more sustainable and fair practices among the actors and agents who participate in these supply chains. This is the case with food hubs, which are seen as organizational strategies of reterritorialization of food systems, which allow small farmers to compete in the markets by building local supply networks [11].

Food markets are understood as places or spaces in which agents interact briefly for exchanging goods, products, and services [7,12]. In such spaces, a set of values is mobilized as the mediator of social interactions between actors. These are the values that will define and build the notions and conventions of quality, locality, origin, and relationship with nature, all of which are central to distinguishing foods that are exchanged in these spaces.

Existing literature on the new food markets and the emergence of alternative food networks is not negligible, especially in countries of Northern Europe and in the United States [13]. This perspective focuses on the processes of localization of production $[14,15]$ and on the reconnection between producers and consumers [16]. The notion of an Alternative Food Network (AFN) has become widely used in discussions on emerging networks involving producers, consumers, and other actors, which constitute new and different forms of agri-food production, processing, and distribution [17]. According to AFN's exponents, these food networks may represent alternatives to the conventional production system, because they reflect both a "quality turn" [18] and a process of (re)localization of the agri-food system $[3,19]$.

Another analytical perspective has recently been developed, which is aimed specifically at examining these alternative processes and mechanisms for food marketing by means of the concept of nested markets $[20,21]$. The construction of these nested markets is also considered by the authors as part of a broader strategy for spatially rethinking and redefining rural development as regards the understanding of the relationships and interactions established by small farmers, who seek more accessible, sustainable, and fair ways of marketing their products. According to Ploeg et al. [9], nested markets emerge from processes of agricultural reterritorialization and from new forms of distribution, which aim not only to reconnect the actors (producers and consumers), but also to establish links between the rural and urban [9].

Nested markets are socially constructed markets that are organized around social interactions between concrete actors who occupy concrete spaces. These markets do not comply with or follow the straightforward and strict conventions of capitalist markets [21]. In this sense, they constitute new organizational and economic mechanisms based on innovative standards and models of trade, which aim to develop alternative ways for food marketing (In the specialized literature on the subject, nested 
markets appear under different designations, according to the discipline dealing with the debate on the local and regional food systems, such as alternative agri-food networks [22], short food supply chains [23], or values-based food supply chains [24]). In turn, these alternative ways and practices are based upon three main dimensions: the notion of quality attributed to food, the definition of local, and their relationship with nature.

It is important to note that these spaces are built in relation to broader markets. They are a market segment that is part of a broader market [12]. The nested markets are not outside of capitalism or the mainstream mode of production of current society. They coexist with and reproduce themselves in relation to conventional markets [25] and, therefore, they are compelled to adapt. Although they often succeed in enduring and flourishing, sometimes they are dominated, constrained, and may even disappear.

As we shall see in the case studies in this article, these nested markets are continually in contact and interacting with conventional markets, encouraging the creation of mechanisms and strategies for distinguishing their products and gaining consumers' preference, in order to make this relationship less asymmetrical.

Thus, we argue that, far beyond investigating new nested markets in the context of the dichotomy between conventional and alternative markets, it is necessary to advance discussions and to include the relationship between them in the research agendas, insofar as markets are understood as spaces of interaction that constitute hybrid forms and allow for exchanges of various kinds. In this sense, nested markets aim to take a step forward concerning the theoretical framework on food localization and alternative markets, seeking new analytical elements that, based on the construction of markets for family farmers, may influence rural development practices, policies, and processes.

So, what are the possible contributions of this perspective to rural development and how can we advance the discussions about alternative markets for family farmers? From the framework of the nested markets, we believe that investigating how these markets are constructed and developed in interface with conventional markets can help us to understand their implications for rural development. Therefore, this paper aims to apply the nested market theoretical framework to discuss the construction and dynamics of these markets, especially regarding their interactions with broader markets and their contributions to rural development practices, policies, and processes. To this end, based on this framework, we analyse two empirical cases of nested markets in southern Brazil—one involving rural tourism, at the Caminhos de Pedra route (Stone Pathways Route), located in the city of Bento Gonçalves (RS); and the other comprising a farmers' direct selling market, the Farmers' Market, located in the city of Passo Fundo (RS).

The article is presented in five sections, beginning with this introduction. In Section 2, we discuss the construction and dynamics of nested markets and their relations with the perspective of the AFNs. The objective is to present the key concepts and basic characteristics that define them. We will also discuss their potential for local production and food consumption and the main limitations of these nested markets.

Section 3 is focused on the empirical analysis of two local food markets based on the perspective of nested markets. By analysing the cases of Rural Tourism at the Caminhos de Pedra Route, and of the Farmers' Market, in Passo Fundo/RS, we aim to demonstrate how the dimensions of quality, local origin, and nature are built into these markets, and how these latter are continually interacting with broader agri-food markets.

In Section 4, we will discuss the contributions of the nested markets framework to rural development practices, policies, and processes, and the opportunities it opens up. Finally, in the fifth and final section, we raise some concluding considerations and questions.

\section{Local Production and Consumption of Food: Nested Markets and Alternative Food Networks}

There is growing consensus over the idea that the development of better and more diversified marketing channels is crucial for small-scale farmers to improve their access to markets $[8,9,26]$. 
Conventional markets tend to reduce the options for selling merchandise and buying agricultural inputs, thus creating a kind of squeeze characterized by restrictions on competition, access to information, and attainment of better prices. In order to overcome such restrictions, there has been a growing effort towards improving the markets in which smallholders participate, rather than supporting the isolation of the markets as in the past. (It is also worth pointing out that the debate about markets and family farming is gaining international recognition. A recent discussion about Connecting Smallholders to Markets in the CSF (Committee of Food Security, a body linked to FAO) is dealing with territorial markets, which are quite similar to nested markets, and is highlighting the importance of policies for the construction or connection of markets to smallholders.) The nested markets are part of an emerging and comprehensive array of approaches that try to tackle the matter of smallholder farmers' connections and participation in markets.

These findings regarding the significant role of the modes of food marketing and distribution, and their consequent social relations, which involve commercial exchanges, have urged scholars to propose a new theoretical and analytical framework. Considering markets as central elements for promoting social inclusion of small farmers and as expressions of rural development [8,21], such a perspective has been called nested markets.

Generally, the nested markets are deemed spaces of social interaction within which transaction standards and flows are established, and products and services are structured within time and space dimensions. These standards are a direct result of market failures and of the transformations stemming from the rise of global production and consumption processes. According to Ploeg [12], many traditional food markets are affected and transformed by processes of globalization and by the flows and patterns of interaction they impose. This implies a disruption of the local networks and social ties, as well as of the cultural and material frameworks that sustain these markets. Thus, certain modes of production and kinds of products end up being changed, thereby creating "holes" in which such social relationships cannot be created and/or materialised (for example, in the geographical reference to a product, as in the case of lamb meat analysed by Ploeg [12]).

Therefore, a nested market "[...] is a segment of a wider market. It is a specific segment that typically displays different price levels, distributional patterns of the total Value Added and relations between producers, distributors and consumers than those seen in the wider market. This segment is nested in a wider market. It is part of, but at the same time it differs from it" [26]. Furthermore, they are markets defined by particular boundaries that are quite permeable, so that to allow flexibility and innovation.

In this context, new markets are created, which emerge from the mobilization of a set of norms, rules, and social conventions that seek to reshape the flow of goods and rearrange the patterns and the nature of transactions [26]. That is, to the extent that global markets advance and impose certain standards and rules (production, quality, and marketing standards; sanitary and packaging norms, etc.), they affect and transform local food markets and networks, imposing on these spaces the development of new socio-material structures, and producing new and distinct patterns of transaction and interaction.

The nested markets framework enables us to understand the emergence of new food markets in relation to the development and operation of conventional (wider) markets. In a way, the very failures arising from the conventional markets (the social and economic harm produced, i.e., health problems, inequality for small farmers, environmental impacts) make room for the construction of new practices, processes, services, and products that differ from those found in hegemonic or conventional markets. Although they develop relationally to the conventional markets, the nested markets do not comprise niches within these broader markets. Unlike niche markets, the nested markets are open to products and actors, which can enter and leave these market spaces according to the relationships they are able to maintain within them. In other words, while niche markets are closed to certain products and product standards and rules, nested markets are open and flexible market spaces that allow the emergence of new relationships [20]. According to the nested markets perspective, alternatives to 
the mainstream agri-food model emerge from interactions between the established local/cultural practices and processes (based on re-localization and reconnection) and the conventional mechanisms of governance. This is the major contribution of this framework, which we will develop later on.

Nested markets arise from these interactions, although they differ in relation to wider markets inasmuch as their operation rests on elements like "distinctiveness", "socio-material infrastructures", and "common-pool resources", which we will describe further on. These elements allow us to connect the nested markets perspective with the debate on alternative food networks. However, before a detailed analysis of these relationships, we must deepen our understanding of these structural elements of nested markets.

Distinctiveness is deemed as a primary characteristic of nested markets, and can be built on different dimensions. These dimensions are: price, since the product may differ by being either cheaper or more expensive; product quality, which will be socially defined; production mode, since different production processes can create different products; social organization of time and space, allowing the distinctions of fresh produce and those of local origin; and availability, because the scarcer the product, the greater its distinctiveness will be [26].

Moreover, it is through the transactions and exchanges that distinction plays its key role. According to Ploeg [26], distinction is a feature developed and consolidated throughout the production chain. By being produced in a different manner, food reaches specific consumers who are able to appreciate and recognize this characteristic, and eventually incorporate such a distinction. At the same time, processors and suppliers also incorporate the distinction, which ends up generating symbolic - and positive-relationships between all the actors involved. Such relationships reflect on the quality/distinctiveness of the products and the establishment of social interaction networks.

Finally, these relationship networks—and exchange processes-are embedded in a set of values, norms, and social conventions. Ploeg [26] highlights three levels of exchange in which distinction plays a central role. The first one refers to social construction of quality, which results from interactions between agents participating in the supply chains, ascribing reputation to both products and producers, and generating trust. The second level comprises the material exchange itself and the distinguishing aspects: differentiated products for money and vice versa.

The third level of exchange reveals how distinctiveness is conveyed from producers to consumers through products, and "[...] how this transfer is connected with a reverse flow of appreciation that attributes distinction to the producer" [21]. The author concludes that levels 1 and 3 together constitute a social network. The second level of exchange, in turn, comprises the transaction itself, which is embedded (or nested) in, and dependent on, this social network, which is composed by the social definition of qualities and the associated symbolic exchanges that imply trust and reputation [21].

The second structuring element of nested markets is the development of a socio-material infrastructure. As the products circulating in these markets are distinct from those found in mainstream markets, it is necessary to develop a specific and different set of rules, regulations, and conventions to certify this distinctiveness. It is these socio-material structures (rules and regulations) that allow goods to flow and be recognized as distinct from those found in conventional markets, thus enabling the creation of novelties and innovation (new products and services).

A last feature of nested markets refers to common-pool resources, which play a key role in this dynamic. As much the distinctiveness as the novelties and socio-material infrastructures are all built and function as a non-material common-pool resource, since they connect different stakeholders and enable collective actions aimed at generating mutual benefits [21].

In nested markets, common-pool resources allow producers to obtain additional benefits such as good prices and access to particular groups of consumers. These benefits could not be obtained other than collectively. This is why they are considered "common", for they cannot be appropriated individually. On the contrary, they are able to generate and sustain benefits for all [8].

Therefore, the creation and maintenance of these new markets are only possible insofar as a set of socially shared rules and norms becomes institutionalized at the local level and is (re)created on a daily 
basis by actors and organizations. It is by means of these norms that products and services acquire distinctiveness and that a socio-material structure different from those of mainstream markets can be built. That is, common-pool resources are a result of the creation of new markets and the elements that originate them.

In this sense, the definition of such structuring features of nested markets enables us to relate them to the general debate surrounding the alternative agri-food networks, which has pervaded sociological food studies.

\section{Nested Markets and Alternative Food Networks}

Generally, AFN can be defined as the set of relationships between actors and institutions taking part in food supply chains (production, processing, distribution, marketing, and consumption). In other words, it refers to the possibility, for various local actors and institutions, of organizing themselves by creating mutual bonds and designing marketing strategies for their products, which are distinct and related both to social and cultural values and to the particular interactions of each territory or region where they emerge [22].

Therefore, the emergence of these networks is associated with various responses and criticism towards the mainstream production and consumption model. Such responses are built and established in accordance with the historical, political, social, and cultural characteristics of the places where they emerge [25]. Thus, the alternative nature of such processes lies in their ability to develop different modes of production and consumption (e.g., fair trade, special, and certified products; local/regional products, short supply chains, farmers' markets) grounded on cultural meanings and relationships that emerge as guidelines for (new) practices and local services, re-valuing food knowledge and, in other cases, reconnecting producers and consumers $[27,28]$.

Although implicitly suggesting that such networks are alternatives to the hegemonic model of food production and consumption, this framework does not consider these new practices and services as opposed to the conventional food model, but rather as a different response to the adverse consequences that arise from this model. This implies a relational interpretation of these processes, based upon the assumption that there are no clear (and actual) boundaries between alternative and conventional food production and consumption models, but rather a muddle of overlapping, juxtaposing, or intersecting networks operating within the same socioeconomic space [27]. (Some authors have warned against "the local trap"-the risk of taking 'the local' as a space free from power relations and competitiveness- thus suggesting that the alternative food networks must be seen as strategies, not as solutions per se to the conventional model [29]. Even so, one must not confuse the spatial relationships enabled by these networks (local production) with the social relations underlying them (trust, reputation, power, and so on) [22].)

In this sense, the nested markets framework gets closer to that of alternative food networks, insofar as both propose a relational analysis of the practices and processes that have been emerging in contemporary rural environment. Although drawing on different theoretical references (nested markets follow institutionalist and actor-oriented approaches), both perspectives focus their analyses on local markets and on the curtailment of distance between producers and consumers, especially regarding trust relationships, processes for building products quality and distinctiveness, and sustainable consumption practices. Furthermore, they share the idea that local markets emerge from their interaction with the global/conventional market.

Two assertions or inferences arise therefrom. The first one is the recognition of the hybrid and multiple nature of the markets, either food markets or others. In the realm of alternative food networks, food markets are deemed as hybrid spaces whose mechanisms of governance are defined by both conventional standards, norms, and values (competitiveness, efficiency, power) and alternative relationships and conventions (reciprocity, friendship, reputation; interknowledge) [25]. As to the concept of nested markets, it comprises a multitude of markets (and modes of trade and commercial 
exchange) that coexist—whether they be conventional or alternative-entailing a diversity of practices and social interactions that create specific mechanisms of marketing and distribution.

The second assertion arising from these perspectives relates to the fact that, despite emerging from their relations with conventional markets, alternative markets differ from these latter by allowing the development of more just and sustainable social and economic relations. In other words, the major difference (and contribution) of nested markets and alternative food networks perspectives lies in the notion that the alternative nature of local food markets results from their ability to strengthen local mechanisms and forms of governance that are founded on non-conventional values and social codes (friendship, trust, reputation, reciprocity, interknowledge; otherness).

However, the nested markets framework goes beyond that one of alternative food networks, because it places the construction of (local) markets on the direct relation that these latter maintain with the conventional markets. In this sense, the nested markets framework helps to understand the issue pointed out by Sonnino and Marsden [25], that between conventional markets and alternative food networks there are interfaces and a confluence zone, and not necessarily an opposition. The transformative potential of nested markets lies in their ability to show how the contradictory general development processes, based on the consolidation of conventional markets, are themselves generating responses and alternative processes of development, exemplified in the emergence of a diversity of food supply and consumption practices.

These mechanisms and forms of local governance (embedded in alternative values) are those responsible for the construction and management of the (new) food markets, since they allow elements such as distinctiveness, socio-material infrastructure, and common-pool resources to be recognized and socially legitimized by the actors, thus ascribing alternative and distinct characteristics in relation to other markets to local products and services.

In order to better understand these dynamics and operation of nested markets, in the next section we will analyse two empirical cases of development of local food markets, aiming to demonstrate how they both have emerged from their interaction with wider markets.

\section{Nested Markets in Brazil: Rural Tourism and Direct Selling Markets}

Drawing on the definitions and dynamics attributed to nested markets, this section aims to analyse two distinct cases of food markets and verify to what extent these cases can be interpreted in the light of the perspective used here.

The first case refers to the rural tourism market of Caminhos de Pedra Route, in Bento Gonçalves, a city located in the mountain region of Rio Grande do Sul (RS), in Brazil. The second case relates to the Farmers' Market located in the city of Passo Fundo, located in the northern region of Rio Grande do Sul. These two local markets were chosen on the grounds of the differences between them. While rural tourism can be considered a recent market activity, resulting from both the transformations occurred in contemporary rural environment and the development of non-agricultural activities and services, the direct sales market constitutes a traditional method of food trade used by farmers to sell their products. Despite these differences, these two markets share some characteristics-especially those related to social embeddedness of economic activities in social rules and norms-that allow them to be analysed as examples of nested markets, as described below.

\subsection{Landscape and Rural Life: The Case of Rural Tourism of Caminhos de Pedra Route-Bento Gonçalves/RS}

In a context where an increasing number of rural families are developing activities other than agriculture as a means of income diversification, new notions of rurality have attracted attention to the rural space not only for its agri-food productive character, but above all as a space for sociocultural integration where various activities can be developed, including educational, manufacturing, political, environmental preservation, services provision, and even entertainment. In this sense, rural tourism has become a reality in Brazil and stands out as a potential market in terms of both services 
provision and commercialization of local food products, given the growing demand by people seeking rural amenities.

Data presented in this section were collected from 14 to 22 June 2013 [30] for research in the field of rural development. Applying a qualitative approach and the method of case study, the research resorted to semi-structured interviews with owners of houses engaged in the local tourist route, as well as with visitors of the route and one representative of a relevant organization. In total, nine interviews were carried out with owners of the houses included in the route, 63 with tourists visiting the route, and one in-depth interview was conducted with a representative of the organization that connects local small entrepreneurs and farmers. All interviews were open for allowing more autonomy to the researcher and enabling new insights and information from the interviewees. The interviews aimed primarily to analyse the marketing strategies applied in the route, from the perspective of the producers, and to understand the profile and motivations of the visitors of the route.

Caminhos de Pedra is a rural tourism route developed in the district of São Pedro, in the city of Bento Gonçalves (RS), located 109 kilometres away from Porto Alegre, the capital of Rio Grande do Sul state. In the 1970s, a local economic downturn imposed hardships on small-scale farming, which specialized in growing grapes and producing artisanal wine. The entry of large companies into the winery sector, with the purchase of small businesses and cooperatives, disrupted the production system of artisanal wineries and set up an oligopolistic structure in the region's winemaking sector [31]. Such circumstances were triggered by the project of agriculture modernization in Brazil, strongly supported by the state, which aimed to produce more food at lower prices, turning the countryside into a supplier of raw materials and workforce to the cities.

Within this context, grape prices have dropped significantly (the so-called squeeze), making farmers increasingly vulnerable and dependent on credit to purchase inputs and machinery. In the case of São Pedro district, the construction of a new highway that isolated the village from the economic route, and a series of ground frosts that nearly annihilated grape production, resulted in a major depression in the local economy, leading to decreased purchasing power and loss of self-esteem by locals.

Thereupon, a tourist project was launched to preserve São Pedro district's architectural heritage. The project was conceived by Tarcisio Michelon (an engineer) and Júlio Posenato (an architect). Michelon, who was born in Bento Gonçalves, ran the hotel Dall'Onder, which belonged to his family, and believed that both architecture and local culture had potential for attracting tourists. Posenato, in turn, who used to write about the Italian immigration architecture in the state, was an enthusiastic advocate for the preservation of this heritage, but was faced with the failure of the state to develop such projects. The meeting of these two external agents, on their own initiative, resulted in the Caminhos de Pedra Project, which sought a good rationale for getting funds to enable the preservation of this heritage: tourism promotion was the answer.

At first, there was scarce public support for the development of tourism in São Pedro. The first step was conducting a historical heritage survey, which found a large collection of historic houses (made of stone, wood, and masonry) that offered easy access and interesting tourist potential, but which were significantly deteriorated due to lack of maintenance over time. At this stage, it was necessary to persuade local farmers, weakened by the economic circumstances at the time, to believe in the possibility of generating income through rural tourism and to work together to achieve this goal.

Afterwards, initiatives were developed aimed at the restoration and renovation of architectural heritage, and farmers were provided with assistance to develop a basic infrastructure for receiving visitors. On 30 May 1992, the first group of tourists from São Paulo was received there by the first four families engaged in the project. The subsequent development of the tourist route led to the foundation of the Caminhos de Pedra Association. Tourism has been the main argument for raising support for this project, in view of the prospect of income generation based on architectural heritage.

Caminhos de Pedra Association was founded in 1997 with the support of Serviço Brasileiro de Apoio às Micro e Pequenas Empresas (SEBRAE) (Brazilian Technical Support for Micro and Small 
Enterprises), drawing on the success of the project's early ventures. The Association is a non-profit institution aimed at gathering people for carrying out common goals.

The association brings together local entrepreneurs and other members of the tourism trade and seeks to promote the cultural heritage of Italian immigrants, settled in the area since 1875, with regard to both historical buildings and the intangible heritage composed by dialects, arts, practices, folklore, etc. The project is currently supported by funds made available through a national law on cultural promotion (Lei de Incentivo à Cultura) by the Department of Culture of the Rio Grande do Sul State [32], as well as by the symbolic contributions of its associate members. In 2009, the Caminhos de Pedra Route was granted with the recognition as Historical and Cultural Heritage of RS, by means of the State Law 13177/09.

Thus, the emergence of Caminhos de Pedra Route as a rural tourist enterprise was marked by a strong presence of external and private agents. Only later did it gain legitimacy in the local community, as local farmers began to get involved through the establishment of the association, and the government, especially local public administration, decided to support the initiative by providing infrastructure (improvements on the road, access, signposting). Further support was provided by the Tourism Department and by national and regional tourism bodies, through marketing, communication and planning; and by Sebrae and Senar (Serviço Nacional de Aprendizagem Rural, a Brazilian technical support for rural learning), through tourism qualification and training courses. Other relevant actors in this trajectory are urban consumers (tourists and excursionists) as well as travel agents, tour operators, and the Caminhos de Pedra Association.

The route currently has 24 spots for visitation, including restaurants, a lodging, and historical houses for guided tours. The so-called visitation spots are private enterprises that serve tourists offering some kind of product or service, such as food, guided tours, tasting, and shops with local products and handicrafts, among others. Some of these places charge an entrance fee.

As for the owners, most are family farmers who share their time and work between farming and tourism activities. However, it was observed that the route's success and consolidation has attracted some urban entrepreneurs who acquired properties in São Pedro and developed their tourism enterprises. These enterprises represent a more conventional segment of tourism within the route. Therefore, these actors interact and compete in the same scenario with the family farmers, thus ascribing a hybrid and multiple character to the rural tourism market, which encompasses interactions between alternative and conventional types of exchange.

Most products marketed in Caminhos de Pedra Route are produced either at the properties on the route or by producers from this same district and region, which allows them to advance the local economy also outside the tourism route. It is worth noting that some properties also offer manufactured products, either food or souvenirs. This is also an indication of interaction and hybridization between alternative and conventional markets, and should be regarded carefully by both researchers and farmers. In addition, depending on the availability and seasonality, other products may be included at the outlets. This is the case with pecan nuts, as observed during fieldwork in 2013 [30]. One of the farmers, realizing that tourists gathered the nuts fallen on the ground during the tour and demanded that product, decided to pack the nuts and sell them at the shop located on the property.

Some aspects of the tourism market are essential for discussing its distinctiveness and embeddedness in social networks. As a channel that sells products and services through direct contact between producers and consumers, rural tourism is part of a large social network that promotes the exchange of experiences, information, feedback, and symbolic exchanges based on reputation and trust [12]. These latter are crucial elements both for food trade and distinctiveness and for assuring the return of the tourist to that route. The relationships established during exchanges will determine visitors' satisfaction and their willingness to come again and recommend the place to family and friends. The field research conducted at Caminhos de Pedra route revealed that "word of mouth", i.e., the suggestion by tourists to others, is the main and most effective way to make the route known, 
according to the interviewed owners [30]. This significantly reduces the costs of marketing and advertising, which are often unaffordable.

Moreover, being in touch with visitors allows farmers to get their opinions and suggestions for improvements and further demands, thus fostering the development of new products and services (e.g., pecan nuts) and feeding a virtuous circle of the development of common-pool resources.

Another key feature regarding cost reduction is the fact that sales through tourism are carried out in-house, i.e., farmers do not need to leave their properties to sell their products in the city-which would mean transportation and food expenses, for example-or to deliver them to third parties. The tourists themselves travel to the spot, in this case, the countryside, for leisure and consumption activities, thus helping to reduce producers' costs and allowing, in addition, greater autonomy to producers, despite the intensive work on weekends and holidays and, depending on the property and the kind of service offered, the possible costs of hiring employees.

Regarding distinctiveness aspects, foodstuff marketed through this channel-jams, sausages, cheeses, wines, juices, breads, and pastries—can be considered differentiated at the state and national levels, but they are quite common in the region of Serra Gaúcha. However, the tourist product that is offered has a special appeal that distinguishes it from other competitors in the region and conventional forms of tourism: the stone houses, along with the culture and way of life of their residents. The distinctiveness and attractiveness of rural tourism, as a special kind of market, will rely on the rural aspect of the places [12].

The analysis of the motivation of tourists for visiting Caminho de Pedra Route [30] showed that the most valued aspects of the route are: the community's cultural-historical features, mainly related to the landscape-materialized in stone houses and natural heritage; the local culture of Italian immigrants' descendants; the rural life aspects, such as local cuisine, climate, and rural environment; and the possibility of breaking up one's routine. In this context, such aspects are the main attraction of the tour and can be considered common-pool resources [12] since they can be used by locals for attracting tourists, adding quality and differentiation to products, producing collective multiplier effects, and reducing transaction costs. Thus, they constitute the basis for tourism development while contributing to their own conservation.

It is worth noting that the common-pool resources can be both tangible-such as the natural landscape, stone houses, and local food offered-and intangible, as in the rural way of life-more peaceful and harmonious; and the culture, crafts, and the own reputation of Caminhos de Pedra's brand in the region. Tourism, while contributing to a diversification of community activities and to generating employment and income, can help preserve these resources that are essential for local development, contributing to their maintenance and appreciation by the local population and public administration. However, one cannot deny the risks posed to these common pool resources by possible uncontrolled growth of tourism. In this route, we could observe the arrival of tourist buses of large travel agencies, which can be seen both as the inclusion of conventional tourism in this market and as a threat to heritage.

Therefore, the dynamics of the construction of a rural tourism market in Caminhos de Pedra Route was triggered by the crisis of small farming in the 1970s, characterized by the squeeze of grape and wine prices, which created favourable conditions for the development of multifunctionality as a way to seek new sources of income for the local population. Thus, the dynamics of the conventional market and its local impacts created the context for the construction of new forms of income generation and social reproduction in this locality. By means of the joint efforts of multiple actors (external private sector, local governments, farmers, local association, tourism agencies and tour operators, urban consumers, and tourists), a new market for local family farms has been created through the development of tourist activity in the rural area, which is distinguished from conventional tourism for being mainly based on lifestyle, products quality, culture, and heritage, and directly linked to agricultural production. 
The creation of a socio-material infrastructure, i.e., a set of rules and standards put in place by the involved actors, allows the establishment of these flows and the development of common-pool resources, which may bring collective benefits to this community and allow the continuation of this dynamic. The partnerships and the norms and standards that allow local training courses on tourism and agroindustry promoted by organizations like Sebrae and Senar; the construction of tourism infrastructure by the municipal government; the efforts to get the support of federal government through the legislation for promoting culture; and the exchange of information and experience with the tourists-all these can be seen as examples of socio-material structures.

Lastly, we can observe that conventional markets are always intertwined with the dynamics of the rural tourism market in the Caminhos de Pedra route. Since the construction of this new market-starting with the wine and grape markets' failures that created the conditions for multifunctionality - until the consolidation of the route with the subsequent entrance of external actors and constant hybridization of products and practices, the coexistence of different logics of exchange has shown that this nested market also has permeable boundaries that allow for flexibility and innovation.

\subsection{Farmers' Markets Framed by Rural Background, Social Trust, and Friendship: The Case of Passo Fundo/RS}

Data presented and analysed in this section stem from a broader study in the area of rural sociology [33], based on a case study focusing the Farmers' Market of the municipality of Passo Fundo, state of Rio Grande do Sul. Data collection was carried out through 25 semi-structured in-depth interviews, 12 of them with stallholders, seven with consumers, and three with representatives of municipal institutions related to rural issues. In addition to the interviews, 45 semi-structured questionnaires were applied to consumers at the farmers' market and another 25 to stallholders [33].

The use of these two strategies for data collection was aimed, on the one hand, at characterising the socioeconomic profile of the main participants of the Farmers' Market (consumers and producers). On the other hand, it sought to understand the interests and strategies of the producers in the construction of this market, as well as the motivations and values that move consumers. This allowed us to find some of the main characteristics of nested markets [26] in the Farmers' Market of Passo Fundo, such as distinctiveness of products through quality construction; development of a socio-material base by mobilizing specific values; and the construction and definition of common-pool resources in that area. These characteristics will be analysed in this section.

The Farmers' Market of Passo Fundo, in Rio Grande do Sul, is a market outlet created in the mid-1970s by farmers who saw an opportunity to increase their income by selling their products directly to consumers. At first, sales were made at a town square, but over the years, and with the support of several institutions, the municipal administration provided an indoor space, with better infrastructure for keeping and selling the products.

It is worth noting that this process developed from an almost individual move by producers, who saw in the creation of a direct sales channel a possibility for productive and commercial innovation, which has gradually developed.

Following this beginning, the development of the market was fostered through the establishment of a network of institutions and actors that teamed up in order to provide the city's inhabitants with access to local and quality food. This network comprises, besides the Stallholders Association (created in 1996 and now responsible for the management of the farmers' market), the support of the Rural Workers Union-which has been engaged since the beginning of the producers' market and is responsible for providing farmers with services and guidance (credit, financing, inclusion in government programs); the municipal branch of EMATER (rural extension agency)—which provides support on technical aspects of production and marketing guidance; and the municipal administration, through the Home Affairs Department (SECRINT), which until 1996 was responsible for managing the producers market and, after the establishment of the Stallholders Association, remained in charge of monitoring the prices and quality of the supplied products. This network is an example of how 
individual and collective interests may be articulated to build new markets, and also exemplifies the construction of a socio-material structure that supports a new market.

Today, the market gathers 66 stallholders, who are small farmers from the rural areas of the municipality. These farmers produce food and traditional varieties of the region, observing production seasonality and using traditional techniques and knowledge related to the local culture and ethnic origins. The market provides access to fresh produce, which furthermore represents the social and cultural features of the territory.

The search for such products-considered to be of higher quality-is the main reason why consumers attend this market. For consumers, the main concerns when purchasing products here are acquiring products of rural origin, and valuing both small farmers' way of life and the traditional techniques used in preparing the food products.

In this sense, by analysing the Farmers' Market using the fundamentals of the nested markets perspective as proposed by Ploeg [12], we note that the distinctiveness of the products is related to two main elements: the prices charged and their rural origins.

In view of the presence in this market of stallholders that are not producers (called fruit sellers), there was an agreement between the participants of the market to make the sales relationships and the prices charged more fair. As these fruit sellers operate as small traders, buying local and exogenous products from farmers and warehouses, they do not suffer from the climatic hazards (drought, frost, etc.) that may affect local produce, and thus face no major difficulties in meeting consumer demand and keeping prices reasonable. That is, due to the coexistence of conventional and alternative practices within the farmers' market, it was necessary to create social regulatory mechanisms in order to guarantee fairness in economic transactions among all stallholders.

Therefore, given these asymmetries regarding farmer stallholders (who often do have not many products to offer, especially during winter) a fixed price system was created, which is mediated by the Municipal Home Affairs Department (SECRINT) responsible for the agricultural policies. To this end, every month a survey is conducted by an agent designated by SECRINT on the prices of the main products traded at the farmers' market, at about 10 grocery stores in the city. Following this survey, an average price is calculated for each product and tabulated. Stallholders sell their products at prices $20 \%$ lower than those of the table. Hence, the prices charged at the producers' market become a distinctive factor, attracting a considerable number of consumers, since, on average, these prices are lower than those charged in other markets [33].

Another factor that distinguishes the products of the Farmers' Market is the quality associated with their rural origins. As highlighted by Ploeg [12], quality generally stems from a historical and cultural process of embeddedness, observed in certain regions, which ascribes distinction to products or to the ways they are produced. In the case of the Farmers' Market, quality construction is closely linked to the rural origins of the products and to the fact that they were produced by small farmers, which, in the consumers' view, indicates greater care and traditional production. As explained by one consumer:

"(I buy at the Market) because, usually, their salad ... , you always get a good salad ... at the grocery store it is usually wilted ... at other markets than that of the producers-greengrocers, you know?, you get there and their salad is already wilting. So, for me, quality is buying this fresh product that even tastes different (...) so people identify with it and buy, because they know the product is homemade, is made with care ... for example, I know that their pasta is homemade, so I always buy it" [33].

This statement makes clear that the quality attributed to the products of the Farmers' Market is associated with intangible aspects related to the possibility of buying "fresh", "homemade" food, produced right there, near the city, and which differs in its taste and the way it is made.

The second dimension of nested markets described by Ploeg [12] relates to the development of a socio-material basis that enables goods and services to flow through alternative marketing mechanisms. This socio-material base is nothing more than a specific and differentiated set of rules, standards, 
and conventions that are mobilized to confer distinctiveness to such markets. As already mentioned, the creation of the farmers' market Feira do Pequeno Produtor is a result of the construction of a network that connects institutions related to the rural areas, which are concerned with making local and quality food available to the people of the municipality. This network supervises the products offered at the farmers' market and also contributes to creating the norms and standards that guide the operation of the market and the transaction flows, thus developing a socio-material structure that distinguishes the farmers' market from other markets (e.g., by means of pricing).

Furthermore, this socio-material structure can be observed among the residents of the city, in a shared representation regarding the rural origins of the products and an appreciation of the way of life of small farmers. In particular, the inhabitants of the city share a common rural past, which is seen as positive, thus attributing a superior quality to products offered at the market that are made "as my mother used to do" or in a traditional way.

This rural origin of the products is associated with food products being quality and natural, and, because they were produced by family farmers, it is believed that the food is more healthy and tasty. This is also reflected in the appreciation of local ways of life and products. According to one respondent:

"Well, the main reason was ... acquiring products generally produced here in our region ... by small producers ... products from our countryside ... so to give preference to our producer. People who grew up in the countryside have to cherish it" [33].

Finally, the last dimension that characterises nested markets concerns the development of common-pool resources. According to Ploeg [12], common-pool resources are key to the development of new markets for products and services, and constitute a set of shared values that connect the various actors (producers, consumers, mediators) that take part in these markets. Furthermore, these resources account for the social legitimation of the distinctiveness of products sold through nested markets.

In this sense, common-pool resources can be deemed as values on which exchanges and trade are based. In other words, these resources are responsible for building the processes of social embeddedness of economic transactions.

At the Farmers' Market of Passo Fundo, economic transactions are nested in relationships of trust associated with values of friendship, interknowledge, and local varieties of products. While traditional practices and knowledge related to food production and processing confer credibility to products sold at this market, the prospect of interacting directly and creating social bonds with stallholders generates friendship among the actors, which is reinforced by the interknowledge assigned to the rural. Besides strengthening friendships, interknowledge provides social legitimacy for small farming ways of life and production.

This produces a cycle of legitimacy and positive evaluation around the Farmers' Market, since the agents attend it because they trust the products' quality-attributed to their rural origin and to the ways they were produced-and because they appreciate the friendships and mutual interknowledge. Thus, both traditional knowledge and techniques used in food production and social relationships contribute to a shared set of social conventions, which culminates in generating trust and consolidating the Farmers' Market.

These friendly relationships are also responsible for expanding the social networks that constitute the market, since the stallholders rely on friendly relationships to sell their products to restaurants and small grocery stores, as well as to acquire the products to be sold at the market (in the case of fruit sellers). In other words, the friendly relationships allow sellers to extend their commercial links beyond the market space, thus connecting this nested market with wider ones. However, it is important to note that the relationships with broader markets, although mediated by friendly relations, are usually based on conventional social norms. In the case of small farmers, sales to other markets imply price appreciation (higher than those charged at the farmers' market) and pricing based on the amount of products sold. In other words, the market of the small farmers is connected with other markets. 
Therefore, the food market represented by the Farmers' Market of Passo Fundo can be deemed an example of a nested market, since it is possible to identify within it the features and dimensions that define these spaces [12]. Moreover, it was observed that this market is based on an established and shared specific set of rules, values, and norms, which eventually brings together concrete actors who will interact, which ensures its uniqueness and distinction when compared to other spaces of food trade.

\section{The Nested Markets' Contribution to Rural Development}

We have been experiencing a change in our understanding of the role of markets in the social and economic reproduction of farmers and in the way consumers access goods and perceive the role of agents within the food supply chains. The development of new and differentiated products and services, which carry higher value added, has been a way for farmers to face the decrease in income associated with agricultural activities (resulting from the squeeze in prices of products), which has led many of them to abandon conventional and commodity markets. Thus, multifunctionality emerges as a trend and becomes a catalyst for the construction of new markets for farmers to trade their products, raise their incomes, achieve greater autonomy, and improve living conditions in rural areas.

The conventional agri-food system continues to promote processes of subordination via entry into long agri-food supply chains, in which producers are integrated as mere providers of cheap primary raw materials. However, everywhere, increasing cases and experiences have been emerging, which are clearly grounded on another model of market interaction and exchanges, based on social and cultural values, and which are mobilized by the farmers themselves and able to build alternative (and more autonomous) practices and processes of commercialization. These processes teach important lessons for (re)thinking rural development itself, which is no longer related to just the improvement of physical infrastructure or creation of social assistance programmes, as it was in the 1970s, when it consisted basically of a program aimed to those who did not afford technological modernization. Rural development now means, more and more, building markets that value differentiated products and services to, on the one hand, restrain the subordination by the dominant model, and, on the other hand, confer more autonomy and room for farmers to manoeuvre.

When Ploeg et al. [8] developed the analytical framework of nested markets (Figure 1), they emphasized Bernstein's recommendation [34] to always question who is in control or command of the markets; that is, who are their owners and what power relations are in place? The key questions in this regard are: Who builds the markets? What is the capacity of agency of the actors involved in this process? Who gains and what is gained with the construction of these nested markets? What are the asymmetries created? And, finally, what is the destination of the generated surplus, and who appropriates it? Based on this framework (Figure 1), in a subsequent work, Schneider et al. [35] explore other key issues highlighting the relevance of nested markets for the practices, processes, and policies of contemporary rural development.

The new nested markets analysed in this article also exist elsewhere and are generally supported by short circuits coordinated by farmers and, in some cases, customers (as in the case of the Solidarity Purchase Groups-GAS throughout Italy and the Agroecological Integration Group in Porto Alegre, Brazil). The connection between production, processing, distribution, and consumption of food is a central aspect that distinguishes nested markets from conventional agri-food markets, whose socio-material infrastructure is controlled by large corporations. According to Schneider et al. [35], this aspect remarkably distinguishes them, once in nested markets the socio-material infrastructure that enables processes to flow constitutes a common-pool resource, and, thus, it belongs to the producers and consumers who participate in these markets. Therefore, it is important to note that the nested markets remain under the ownership and control of the different agents involved in its constitution, from farmers to consumers. The increased autonomy and decision-making capacity retained by these actors enable them to appropriate the generated economic surpluses and thus contribute to rural development practices and processes in general. 


\begin{tabular}{|c|c|c|}
\hline Who owns what? & $\begin{array}{c}\text { General agricultural and food markets } \\
\text { processing, distribution and the } \\
\text { consumption of food are controlled by } \\
\text { food empires. }\end{array}$ & $\begin{array}{c}\text { Newly emerging markets } \\
\text { consumption of food. These short } \\
\text { circuits are owned or co-owned by } \\
\text { farmers (and sometimes) } \\
\text { consumers. }\end{array}$ \\
\hline Who does what? & $\begin{array}{c}\text { The role of farmers is limited to the } \\
\text { delivery of ray materials for the food } \\
\text { industry. }\end{array}$ & $\begin{array}{c}\text { The role of farmers is extended to } \\
\text { embrace on-farm processing, direct } \\
\text { selling and the redesign of } \\
\text { production processes that better } \\
\text { meet consumer' expectation. }\end{array}$ \\
\hline Who gets what? & $\begin{array}{c}\text { The distribution of value added is highly } \\
\text { skewed: most wealth is accumulated in } \\
\text { food empires. }\end{array}$ & $\begin{array}{c}\text { Farmers get a higher share of the } \\
\text { total value added. }\end{array}$ \\
\hline the surpluses? & $\begin{array}{c}\text { Accumulated wealth is used to finance } \\
\text { the ongoing imperial conquest (take- } \\
\text { over of other enterprises) }\end{array}$ & $\begin{array}{c}\text { Extra income is used to increase the } \\
\text { resilience of food production, to } \\
\text { strengthen multifunctional farming } \\
\text { and to improve livelihoods. }\end{array}$ \\
\hline
\end{tabular}

Figure 1. Framework of analysis-A comparison of the general agricultural and food markets and the newly emerging markets [8].

Another important contribution that nested markets bring to rural development lies in the role played by actors. In conventional markets, actors involved in the supply side play a complementary role simply by delivering raw materials to the industry according to the standards imposed by large processors and retailers. In nested markets, in turn, it is substantially different, as family farmers, in addition to agriculture activity per se, also participate in processing (on site), commercialization, restructuring, and evaluation, and in the redesign of production processes that better meet consumer expectations.

In this sense, these actors are not socially restricted to the production process, but are continually in contact with consumers through direct sales. This social network allows both consumers and producers to exchange information, get feedback, and voice their expectations [12]. These can be important elements in the development of new products and services, such as the pecan nuts mentioned in this work in the case of the nested market of rural tourism. Moreover, these "new" roles played by farmers involved in nested markets are quite attractive to younger populations, which can help in reducing rural-urban migration [35].

Another noteworthy contribution relates to the distribution of Value Added. Schneider and colleagues [35] argue that in major agri-food markets this distribution is quite biased, so that much of the accumulated wealth remains in the hands of food empires, because the farmers operate only in the delivery of their products to intermediaries, their activities being restricted to just one "link" of the food chain. In turn, in the nested markets, producers act at various stages of the agri-food chain (production, processing, sales), which results in a higher share of the value added appropriated by them. That is, the revenue stays largely in the hands of farmers themselves.

Finally, there remains the issue of the use and appropriation of the surplus produced in the rural space. In the case of conventional agriculture, the accumulated wealth is used to finance the maintenance of its domination, by taking control of other companies, expanding their operating areas and forms of governance, and incorporating markets, products, and services. As for the case of nested markets, surpluses are used to strengthen the resilience of agriculture, processing, and product marketing (such as the development of new products) and to improve the livelihoods of involved actors [35].

These four issues, which comprise the framework developed by Ploeg et al. [8], make it clear that the main contribution of nested markets to rural development practices, processes, and policies is the 
fact that their control is much more in the hands of farmers than in those of the large agri-food chains. These nested markets are part of and are continually connected with the wider conventional markets. However, they have very different forms of governance, in the sense that the autonomy of farmers regarding food production, processing, and commercialization strengthens their capacity of resilience, generates common-pool resources and, accordingly, enhances the possibilities for social and economic reproduction in the rural space.

Ploeg [26] points out that the major issue arising in connection to nested and conventional markets is the imposition of global regulations that comprise the modes of governance of conventional markets on the alternative ones. So, these latter are subject to an extensive set of rules involving production, circulation, and food consumption, which are often incompatible with local realities. This is the case with the requirements found in the food safety systems and the food sanitary standards in Brazil and worldwide, which ultimately generate exclusions, power relations, competition, and inequalities in the agri-food system $[21,36,37]$. In this sense, we believe that nested markets are relevant for rural development practices, since they provide farmers with greater autonomy, security, decision-making capacity, and distribution of income, freeing them from submission to the rules of global food markets.

Finally, and aware of the criticism directed at this perspective, such as the issue of scale [29]—increasingly demanded in today's agriculture — and the conventionalization processes [13,38], there are two major contributions resulting from the adoption of a nested markets perspective. The first relates to the fact that such a perspective avoids falling into defensive localism [22,39] and attributing an exaggerated role to local markets in resolving current problems of food supply, especially in view of the growing process of urbanization.

With regard to this aspect, Goodman et al. [22] warn about the risk of considering "the local" as a space where ethical standards and values can flourish, as the source of the alternative and sustainable practices and, therefore, where the "good" agri-food networks build up. The authors try to deconstruct the idea of a pure localism, exempt from conflict, by proposing the notion of reflexive localism [22]. They argue that this ideal of perfection associated with localism can deny the politics of the locality, with potentially problematic consequences for social justice. Moreover, this can lead to solutions based on doubtful standards of purity and perfection, leaving these markets vulnerable to co-option by the corporate agri-food system, and carrying out "elitist, undemocratic politics of perfection marked by problematic conceptions of social justice and civic tolerance" [22]. Therefore, it is necessary to understand that the "local", per se, may imply both inclusion and exclusion of people, places, and particular ways of life. Similarly, it is necessary to be aware of who sets these limits and standards and how they are defined, which can be deemed as both a challenge and a limitation of this concept.

However, we do not aim, here, to delegitimize the concept of localism, but rather to promote a better understanding of the complexity and the traps of local politics, as well as of the long-term effects of movements controlled by particular groups of people. Thus, instead of focusing the analysis on food localization processes, the nested markets perspective expands the understanding of food markets towards a broader view by means of the notion that nested markets are part of (operating together or even within) conventional agricultural markets.

Another important contribution of the nested markets framework lies in the fact that it does not take the stance or speech of food sovereignty and the need to build an autonomous global food model—as has been advocated by some social movements, such as Via Campesina—capable to develop a new world food order, socially just and able to reconnect nature and society, person, and food [40,41].

The nested markets framework proposes a heterodox view of markets and development processes, arguing that nested (and local) markets coexist with other (conventional) markets and struggle with these for space and legitimacy. This is a clear reference to the idea of coexistence of various forms of commercial interaction, as pointed out by Karl Polanyi [7]. Thus, it is admitted that different markets and mechanisms for exchange and trade coexist simultaneously and that nested markets constitute 
concrete spaces of interaction between specific actors, which are constructed and reproduced within the conventional markets, that is, within the capitalist mode of production.

Therefore, the main question to be examined in future works is related to the reasons why these markets, which are based on often informal interpersonal relationships, continue to exist (and in some contexts to expand). In view of both the growing influence of large supermarkets and retail chains and the requirements for increasingly formalized processes of trade and exchange [42], why markets based on interpersonal relationships (still) endure remains an open question. On what governance mechanisms and values, norms, and social rules have they based their continuing existence and growth? Perhaps the nested markets framework can be considered a new stage within rural studies, especially for those focused on the analysis of markets and the mechanisms for exchange and commercial interaction.

\section{Final Considerations}

This article aimed to apply the nested market theoretical framework to analyse and discuss the construction and dynamics of the alternative agri-food markets, especially regarding their interface with broader markets and their contributions to rural development practices, policies, and processes. It sought to relate the concepts of alternative food networks and of nested markets, trying to outline their main analytical contributions and, especially, to advance discussions on this issue. The cases examined in the light of the nested markets framework, which seeks to include the relations and dynamics with the wider conventional markets, allowed us to illustrate how their dialogues and coexistence happen, and how alternative markets behave towards their biggest competitors. Finally, we discussed the importance of nested markets and their contributions for rural development practices, processes, and policies.

The case of rural tourism on the Caminhos de Pedra Route showed how the crisis in the wine industry led to the development of multifunctionality and the consequent creation of an alternative market based on tourism, aiming to generate alternative income for producers, associated with the preservation of local cultural heritage. As to the Farmers' Market located in the urban area of Passo Fundo/RS, it represents the case of a traditional proximity market created based on the initiative of farmers and the support of a network of institutions and actors, with the purpose of increasing their income by means of direct sales to consumers.

It was observed that both cases represent alternative practices and processes of rural development that have emerged through new nested markets. While rural tourism emerges from a more recent context of a change in rural dynamics-with multifunctional practices increasingly expanding among families of rural workers-and stands out as a potential market both for services and direct sales of local food products, the farmers' market is a more traditional kind of market, which comprises direct exchanges between farmers and consumers, whether commercial or symbolic. Thus, both cases bear features that associate them with the process of social embeddedness that characterizes the nested markets, once they are based on a framework of rules and standards that generate product distinctiveness in relation to conventional markets, and enable the creation of common-pool resources based on collective efforts.

It is also noteworthy that the influence of the conventional food market on these cases, whether through the presence of large tourism enterprises in the Caminhos de Pedra Route or through the presence of non-producer stallholders within the Passo Fundo Farmers' Market, shows that nested markets do not operate in isolation, but coexist and are continuously in connection with broader agri-food markets, in terms of competition, regulation, or even appropriation. Therefore, it is important to create mechanisms and strategies that allow us to distinguish the products and gain consumers' preference by means of rural development practices, processes, and policies that make this relationship less asymmetrical. The main force of the nested markets lies in their relationships with the conventional markets. Rooted in a social network and a set of social norms, rules, and conventions that enables their distinctiveness and the creation of common-pool resources, the nested markets allow for greater 
capacity of resilience and autonomy by farmers in the face of conventional markets and their forms of governance, which impose global regulations and standards for food production, marketing, and consumption. In this sense, despite the aforementioned criticism and limitations, such as the scale and risks of conventionalization and of defensive localism, the nested markets constitute increasingly robust strategies for rural development, able to create opportunities for families' success in the rural space.

Acknowledgments: We appreciate the careful reading and suggestions of the reviewers of the paper. Usual disclaimer apply.

Author Contributions: All authors contributed equally to the conception, analysis and writing of the paper.

Conflicts of Interest: The authors declare no conflict of interest.

\section{References}

1. Cleveland, D.A.; Muller, N.M.; Tranovich, A.C.; Mazaroli, D.N.; Hinson, K. Local food hubs for alternative food systems: A case study from Santa Barbara County, California. J. Rural Stud. 2014, 35, 26-36. [CrossRef]

2. Ilbery, B.; Watts, D.; Simpson, S.; Gilg, A.; Little, J. Mapping local foods: Evidence from two English regions. Br. Food J. 2006, 108, 213-225. [CrossRef]

3. Sage, C. The transition movement and food sovereignty: From local resilience to global engagement in food system transformation. J. Consum. Cult. 2014, 14, 254-275. [CrossRef]

4. De Schutter, O. Final Report: The Transformative Potential of the Right to Food; Report to the 25th Session of the Human Rights Council HRC/25/57; Human Rights Council: New York, NY, USA, 2014.

5. Wiskerke, J.S.C. On places lost and places regained: Reflections on the alternative food geography and sustainable regional development. Int. Plan. Stud. 2010, 14, 369-387. [CrossRef]

6. Ploeg, J.D.; Renting, H.; Brunori, G.; Knickel, K.; Mannion, J.; Marsden, T.; de Roest, K.; Sevilla-Guzmán, E.; Ventura, F. Rural development: From practices and policies towards theory. Sociol. Rural. 2000, 40, 391-407. [CrossRef]

7. Schneider, S. Mercados e Agricultura Familiar; Marques, F.C., Conterato, M.A., Schneider, S., Eds.; UFRGS: Porto Alegre, Brasil, 2016; pp. 21-52.

8. Ploeg, J.D.; Jingzhong, Y.; Schneider, S. Rural development reconsidered: Building on comparative perspectives from China, Brazil and the European Union. Riv. Econ. Agrar. 2010, 65, 164-190.

9. Ploeg, J.D.; Jingzhong, Y.; Schneider, S. Rural development through the construction of new, nested, markets: Comparative perspectives from China, Brazil and the European Union. J. Peasant Stud. 2012, 39, 133-173. [CrossRef]

10. Sturgeon, T.J. How do we define value chains and production networks? IDS Bull. 2001, 32, 9-18. [CrossRef]

11. Berti, G.; Mulligan, C. Competitiveness of small farmers and innovative food supply chains: The role of food hubs in creating sustainable regional and local food systems. Sustainability 2016, 8, 616. [CrossRef]

12. Ploeg, J.D. Newly emerging, nested markets: A theoretical introduction. In Rural Development and the Construction of New Markets; Hebinck, P., Ploeg, J.D., Schneider, S., Eds.; Routledge: London, UK, 2015; pp. 16-40.

13. Tregear, A. Progressing knowledge in alternative and local food networks: Critical reflections and a research agenda. J. Rural Stud. 2011, 27, 419-430. [CrossRef]

14. Hinrich, C. The practice and politics of food system localization. J. Peasant Stud. 2005, 19, 33-45. [CrossRef]

15. Eriksen, S.N. Defining local food: Constructing a new taxonomy e three domains of proximity. Acta Agric. Scand. Sect. B Soil Plant Sci. 2013, 63, 47-55. [CrossRef]

16. Kneafsey, M.; Cox, R.; Holloway, L.; Dowler, E.; Venn, L.; Tuomainen, H. Reconnecting Consumers, Producers and Food: Exploring Alternatives; Berg Publishers: Oxford, UK, 2008.

17. Renting, H.; Marsden, T.K.; Banks, J. Understanding alternative food networks: Exploring the role of short food supply chains in rural development. Environ. Plan. 2003, 35, 393-411. [CrossRef]

18. Goodman, D. The quality 'turn' and alternative food practices: Reflections and agenda. J. Rural Stud. 2003, 19, 1-7. [CrossRef]

19. Maye, D. Moving alternative food networks beyond the Niche. Int. J. Sociol. Agric. Food 2014, 20, 383-389.

20. Polman, N.; Poppe, K.J.; Schans, J.W.; Ploeg, J.D. Nested markets with common pool resources in multifunctional agriculture. Riv. Econ. Agrar. 2010, 65, 295-318. 
21. Hebinck, P.; Schneider, S.; Ploeg, J.D. The construction of new, nested markets and the role of rural development policies: Some introduction notes. In Rural Development and the Construction of New Markets; Hebinck, P., Ploeg, J.D., Schneider, S., Eds.; Routledge: London, UK, 2015; pp. 1-15.

22. Goodman, D.; Dupuis, M.E.; Goodman, M.K. Alternative Food Networks: Knowledge, Practice, and Politics; Routledge: Abingdon, UK, 2012.

23. Kneafsey, M.; Venn, L.; Schmutz, U.; Balázs, B.; Trenchard, L.; Eyden-Wood, T.; Bos, E.; Sutton, G.; Blackett, M. Short Food Supply Chains and Local Food Systems in the EU. A State of Play of Their Socio-Economic Characteristics; European Commission: Seville, Spain, 2013.

24. Lyson, T.; Stevenson, G.; Welsh, R. Food and the Mid-Level Farm; The MIT Press: Cambridge, UK, 2008.

25. Sonnino, R.; Marsden, T. Beyond the divide: Rethinking relations between alternative and conventional food networks in Europe. J. Econ. Geogr. 2005, 6, 181-189. [CrossRef]

26. Ploeg, J.D. Mercados aninhados recém criados: Uma introdução teórica. In Construção de Mercados e Agricultura Familiar: Desafios Para o Desenvolvimento Rural; Marques, F.C., Conterato, M.A., Schneider, S., Eds.; UFRGS: Porto Alegre, Brasil, 2016; pp. 21-52.

27. Fonte, M. Knowledge, food and place. A way of producing, a way of knowing. Sociol. Rural. 2008, 48, $200-222$. [CrossRef]

28. Cruz, F. Produtores, Consumidores e a Valorização de Produtos Tradicionais: Um Estudo Sobre Qualidade de Alimentos a Partir do Caso do Queijo Serrano dos Campos de Cima da Serra/RS. Ph.D. Thesis, Universidade Federal do Rio Grande do Sul, Porto Alegre, Brasil, 2012.

29. Born, B.; Purcell, M. Avoiding the Local Trap: Scale and food systems in planning research. J. Plan. Educ. Res. 2006, 26, 195-207. [CrossRef]

30. Salvate, N. Marketing Para o Turismo Rural: Um Novo Olhar Sobre a Oferta e a Demanda no Roteiro Caminhos de Pedra, em Bento Gonçalves-RS. Master's Thesis, Universidade Federal do Rio Grande do Sul, Porto Alegre, Brasil, 2014.

31. Santos, J.V.T. Colonos do Vinho, 2nd ed.; Hucitec: São Paulo, Brasil, 1984.

32. Associação Caminhos de Pedra. Available online: http://www.caminhosdepedra.org.br (accessed on 3 May 2014).

33. Cassol, A. Redes Agroalimentares Alternativas: Mercados, Interação Social e a Construção da Confiança. Master's Thesis, Universidade Federal do Rio Grande do Sul, Porto Alegre, Brasil, 2013.

34. Bernstein, H. Rural livelihoods and agrarian change: Bringing class back in. In Rural Transformations and Development_China in Context: The Everyday Lives of Policies and People; Long, N., Jingzhong, Y., Wang, Y., Eds.; Edward Elgar: Cheltenham, UK; Northampton, MA, USA, 2010.

35. Schneider, S.; Ploeg, J.D.; Hebinck, P. Reconsidering the contribution of nested markets to rural development. In Rural Development and the Construction of New Markets; Hebinck, P., Ploeg, J.D., Schneider, S., Eds.; Routledge: London, UK, 2015; pp. 190-205.

36. Mutersbaugh, T.; Klooster, D.; Renard, M.; Taylor, P. Certifying rural spaces: Quality-certified products and rural governance. J. Rural Stud. 2005, 21, 381-388. [CrossRef]

37. Radomsky, G.; Niederle, P.; Schneider, S. Participatory systems of certification and alternative marketing networks: The case of Ecovida Agroecology Network in South Brazil. In Rural Development and the Construction of New Markets; Hebinck, P., Ploeg, J.D., Schneider, S., Eds.; Routledge: London, UK, 2015; pp. 79-98.

38. Guthman, J. The trouble with 'organic lite' in California: A reijoinder to the 'conventionalisation' debate. Sociol. Rural. 2004, 44, 301-316. [CrossRef]

39. Dupuis, M.; Goodman, D. Should we go "home" to eat? Toward a reflexive politics of localism. J. Rural Stud. 2005, 21, 359-371. [CrossRef]

40. Bernstein, H. Food sovereignty: A sceptical view. J. Peasant Stud. 2014, 46, 1031-1063. [CrossRef]

41. McMichael, P. A comment on Henry Bernstein's way with peasants, and food sovereignty. J. Peasant Stud. 2014, 42, 193-204. [CrossRef]

42. Reardon, T.; Timmer, C.P. Transformation of markets for agricultural output in developing countries since 1950: How has thinking changed? In Handbook of Agricultural Economics; Evenson, R., Pingali, P., Eds.; Elsevier: Amsterdam, The Netherlands, 2007; Volume 3, pp. 2808-2849.

(C) 2016 by the authors; licensee MDPI, Basel, Switzerland. This article is an open access article distributed under the terms and conditions of the Creative Commons Attribution (CC-BY) license (http://creativecommons.org/licenses/by/4.0/). 